\title{
Ensiling Total Mixed Ration for Ruminants: A Review
}

\author{
Antonio Vinicius Iank Bueno $\mathbb{D}^{\mathbb{D}}$, Gustavo Lazzari $\mathbb{D}^{\mathbb{D}}$, Clóves Cabreira Jobim $\mathbb{D}$ \\ and João Luiz Pratti Daniel * (iD \\ Department of Animal Science, State University of Maringá, Maringá 87020-900, Brazil; \\ antonio.iank.bueno@gmail.com (A.V.I.B.); gustavo.lazzari91@gmail.com (G.L.); ccjobim@uem.br (C.C.J.) \\ * Correspondence: jlpdaniel@uem.br; Tel.: +55-44-3011-5415
}

Received: 25 May 2020; Accepted: 17 June 2020; Published: 19 June 2020

check for updates

\begin{abstract}
The interest of ensiling total mixed rations (TMR) for ruminants reemerged in the last decades. In many situations, ensiling TMR has been a sustainable alternative to efficiently handle wet byproducts in ruminant diets. An ensiled TMR typically has a markedly higher aerobic stability than its respective fresh TMR. Ensiling a TMR increases ruminal protein degradability due to proteolysis during storage. An increase of feed efficiency by ruminants fed ensiled rations have been reported, due to the improved starch digestibility in TMR silages containing cereal grains. This manuscript brings an overview of the main nutrient transformations during the ensiling of TMR and their feeding value for ruminants.
\end{abstract}

Keywords: aerobic stability; fermentation; proteolysis; starch digestibility; wet byproducts

\section{Introduction}

Complete or total mixed rations (TMR) are produced by mixing forages, byproducts, concentrates, minerals, vitamins, and additives. From this mix, animals consume the nutrients necessary to meet the requirements of maintenance and production [1].

Ensiling TMR is not a recent practice. The first studies on TMR silage were reported in the 1960s in the United States [2]; meanwhile, the ruminant production industry has shown a renewed interest in TMR silage in several countries, like Japan, China, South Korea, Vietnam, Thailand, Indonesia, Nepal, Israel, Italy, South Africa, Argentina, and Brazil [3,4].

Several benefits have been associated with TMR silages, such as a reduced requirement for labor and machinery (if TMR silage is purchased), uniform composition during storage under farm conditions, the potential for incorporating unpalatable byproducts (if their flavors and odors are altered by fermentation), and high aerobic stability after feedout [3,5,6]. Additionally, TMR silages, similar to other silages, have the potential for commercialization, especially if stored in smaller structures (e.g., bales, bags, and pouches).

In the industry, TMR ingredients are usually mixed in stationary mixer wagons and stored in big bags (e.g., 300 to $400 \mathrm{~kg}$ ) [7] or baled by agricultural compactors [8]. The latter are baler-wrapper combined machines (e.g., Orkel AS, Norway) able to pack the ingredients by tying the bale with plastic film and then wrapping the bale with stretch plastic film. The resulting TMR bales have approximately $1 \mathrm{Mg}$ of fresh matter [8] and high density (324 to $499 \mathrm{~kg}$ dry matter (DM). $\mathrm{m}^{-3}$ ) [4], which has been associated with low nutrient loss during storage, even when the plastic film is damaged [8]. These technologies enable the transport of TMR silage and its flexible use by farmers. The purchase of TMR silage in bags or bales can be a plausible strategy adopted by small farmers without financial resources to invest in machinery and feed storage structures, when TMR silage cost is compatible with their production activities.

When TMR silage is produced on farm, it may be stored in different silo types. In small herds, however, structures such as ag-bags, pouches, drums, and bales are preferred over bunkers or piles, to 
reduce the risk of aerobic deterioration during feedout. In Italy, for instance, silage contractors are currently offering a custom service for baling, wrapping, and hauling 900- to 1200-kg TMR bales on farm [4].

In our view, the main motivation for resuming the use of TMR silages has been the great availability of wet residues coproduced by the agroindustry. Byproducts from the industrialization of cereal grains (including breweries and distilleries), soybean (including the biodiesel industry), sugarcane, cotton, peanut, cassava, vegetables, legumes, and fruits (including citrus growers and wineries) are among the valuable residues available in different regions. Therefore, marketing TMR silages (containing byproducts) has been a promising business opportunity for agroindustry. In small farms, TMR silage has also been proposed as a strategy to improve the conservation of wet forages [9].

Feeding a conventional TMR prepared daily allows the nutritional composition of the diet to be adjusted by using different feedstuffs and supplements (e.g., sources of rumen undegraded protein (RUP) and vitamins) in addition to conserved feeds (hays and whole-crop or grain silages). On the other hand, ensiling a TMR directs all nutrients to fermentation, which ultimately modifies the feeding value of the ration by altering nutrient content and availability.

This review attempts to nutrient changes during the ensiling of complete rations and their feeding value for ruminants. In cases in which studies investigating TMR silage were not available (to the best of our knowledge), we discussed data from other silage types (whole-crop or grain silages). Partial mixed ration (PMR) silage has also gained prominence in ruminant production systems (e.g., dairy cows receiving concentrates in feed stations or automatic milking systems) but is beyond the scope of this paper.

\section{Ensiling Sole or Mixed Ration Ingredients}

Storage under anaerobic conditions is a worldwide method for conserving crops and byproducts with high moisture content. Ensiling rather drying wet feedstuffs avoid the energy cost associated with drying. However, the run of silage fermentation is not always optimum, depending on the DM, soluble carbohydrates, buffering capacity [10], nitrate [11], and microbioma, especially the population of lactic acid bacteria (LAB) [12].

Nishino et al. [5] reported benefits of ensiling wet brewers' grains as TMR silage (538 g DM. $\mathrm{kg}^{-1}$ as fed) instead of ensiling the byproduct alone ( $207 \mathrm{~g} \mathrm{DM} \cdot \mathrm{kg}^{-1}$ as fed). The TMR silage had a lower accumulation of volatile organic compounds with no detrimental effect on the formation of the lactic and acetic acid compared to the wet byproduct ensiled alone. After $40 \mathrm{~d}$ of storage, the TMR silage presented considerable amounts of soluble sugars, whereas in the brewers' grain silage most soluble sugars were consumed during the first days of fermentation. In addition, the TMR silage presented lower yeast counts and higher aerobic stability than the wet brewers' grains ensiled alone. Wang et al. [13] observed lower accumulation of organic acids (lactic acid and acetic acid) in a TMR containing whole crop corn (444 g DM. kg-1 as fed) compared to corn ensiled alone (198 DM.kg-1 as fed). Interestingly, after $56 \mathrm{~d}$ of fermentation both silages had similar amounts of soluble sugars and yeast counts, but the TMR silage presented higher aerobic stability compared to corn silage.

Therefore, combining ingredients with different characteristics before ensiling would improve the conservation process. Mixing dry with wet ingredients may minimize the risk of effluent production and undesirable fermentation. Using ingredients rich in soluble sugars and homofermentative LAB would improve the fermentation, whereas ingredients that promote heterofermentation would improve the aerobic stability of TMR silages.

\section{Effects of Moisture Content on the Conservation of TMR Silages}

In practice, most TMR silages have been produced with a DM content between 400 and 650 g.kg-1 as fed. However, a limited number of trials have evaluated TMR silages with distinguished moisture levels but the same ingredient composition. 
Overall, changing the moisture level might affect the fermentation pattern and nutrient fractionation (e.g., protein) and availability (e.g., starch). Weinberg et al. [6] evaluated TMR ensiled in bales with a DM content of 500 or 650 g. $\mathrm{kg}^{-1}$ and observed lower DM recovery in moister silage (988 vs 999 g.kg-1 DM), which was in line with the lower sugar content in the wetter TMR silage (10 vs $28 \mathrm{~g} \cdot \mathrm{kg}^{-1} \mathrm{DM}$ ). Nonetheless, the moisture content did not affect the in vitro DM digestibility (IVDMD) of the TMR silages (793 g. $\mathrm{kg}^{-1} \mathrm{DM}$ ) after $140 \mathrm{~d}$ of storage. It suggests that other nutrient fraction (e.g., starch) might have gained digestibility during storage, although it was not measured in that study. Improvements in starch digestibility depending on moisture content have been repeatedly reported for cereal crop silages [14,15]. Greater proteolysis in TMR silages with higher moisture content might support this premise [16].

Hao et al. [17] observed no changes in chemical composition (e.g., crude protein (CP), soluble carbohydrates, neutral detergent fiber (NDF), and IVDMD) in TMR silages containing distinguished moisture levels (400, 450 or 500 g. $\mathrm{kg}^{-1}$ as fed) stored up to $56 \mathrm{~d}$. However, the concentrations of fermentation end-products such as lactic acid, acetic acid, and $\mathrm{NH}_{3}-\mathrm{N}$ increased with moisture level accretion. Nevertheless, all TMR silages were aerobically stable for more than $21 \mathrm{~d}$ after feedout, regardless of the moisture content.

In brief, increasing moisture levels in TMR silages affects the fermentation pattern, leading to greater accumulation of fermentation end-products and proteolysis, accompanied by higher DM loss, but minor or no effects on the aerobic stability within the DM range adopted currently. The effect of moisture content on starch digestibility in TMR silages remains to be confirmed.

\section{Nutrient Changes during Silage Fermentation}

\subsection{Carbohydrates}

\subsubsection{Soluble Carbohydrates and Fermentation End-Products}

Water-soluble carbohydrates (primarily sucrose, glucose, and fructose) are the main substrates for microbial growth during silage fermentation [18] (pp. 95-139). After ensiling, fermentation end-products accumulate at the expense of a decrease in soluble carbohydrates.

In TMR silages stored in bales, Weinberg et al. [6] reported a continuous decrease in soluble carbohydrates during $144 \mathrm{~d}$ of storage. Ning et al. [19] observed losses of soluble carbohydrates by $57 \%$ and $54 \%$ in TMR silages containing alfalfa hay or Leymus chinensis hay stored for $56 \mathrm{~d}$ (111 to 49.3 and 117 to 55.8 g. $\mathrm{kg}^{-1} \mathrm{DM}$, respectively). Compared with fresh TMR, Kondo et al. [20] found lower concentrations of soluble carbohydrates in a TMR ensiled without additive (53 vs. 7 g.kg-1 DM, respectively), regardless of the length $(30 \mathrm{~d}$ or $90 \mathrm{~d})$ and temperature $\left(15\right.$ or $\left.30^{\circ} \mathrm{C}\right)$ of storage. Hence, the final content of soluble carbohydrates in TMR silages will depend on their initial contents and the course of fermentation, but most soluble carbohydrates are consumed during the first weeks of fermentation. One may argue that including silages already fermented as TMR silage ingredients would limit the content of soluble carbohydrates, but it contributes to acidify the mixture immediately at ensiling, sparing the number of soluble carbohydrates required for fermentation. In the industry, feedstuffs already fermented have been successfully used as ingredients for TMR silage.

The fermentation end-products are essential for the preservation of TMR silages during storage and feedout. Moreover, these compounds may contribute to animal nutrition by supplying nutrients, altering feed intake, and changing rumen and host metabolism [21] (pp. 279-306). As in conventional silages, LAB dominates the fermentation, and lactic acid is the main end-product in TMR silages, whereas several other compounds may be formed during fermentation (e.g., volatile fatty acids, alcohols, esters, aldehydes, and ketones).

Of course, the final profile of fermentation products will depend on ration ingredients, DM content, storage length, and the temperature and application of additives $[16,22,23]$. Not rarely, TMR silages present high concentrations of lactic acid (e.g., > 80 g. $\mathrm{kg}^{-1} \mathrm{DM}$ ) [6,8,23-25]. Although this finding is seldomly discussed, the inclusion of urea, mineral mixtures, limestone, and buffers 
(e.g., sodium bicarbonate) certainly increases the buffering capacity and stimulates the formation of lactic acid in TMR silages, as previously reported for corn and sugarcane silages treated with alkaline substances [26-28]. The intake of lactic acid has been associated with lower methane production in the rumen fluid (in vitro) [29] and a greater proportion of propionic acid and higher $\mathrm{pH}$ (in vivo) either when lactic acid repriced sucrose [30] or it was supplemented as part of the ration [31], which might be beneficial to animal performance.

Several studies examined the effects of microbial (e.g., Lactobacillus plantarum, Lactobacillus buchneri) or chemical additives (e.g., propionic acid) on the fermentation pattern and aerobic stability of TMR silages. Some studies showed benefits of using silage additives in TMR ensiled with low DM ( $\sim 350$ g. $\mathrm{kg}^{-1}$ as fed) or formulated with specific ingredients (e.g., potato hash; oat crop and common vetch) [23-25,32]. A deeper discussion about the use of silage additives in TMR silages is beyond the scope of this review. However, TMR silages have, in general, low fermentative loss and high aerobic stability, even if untreated with silage additives [33-36].

\subsubsection{Starch}

Once most bacteria responsible for silage fermentation have not been associated with an amylolytic activity, a decrease in starch content is generally not expected due to ensiling $[18,37,38]$. However, Ning et al. [19] observed that amylase activity from silage microorganisms decreased by $75 \%$ and $57 \%$ of the original activity in TMR silages containing alfalfa hay or Leymus chinensis hay, respectively, and that starch losses occurred until the end (56 d) of storage (by $20.5 \%$ for alfalfa hay TMR and by $17.1 \%$ for Leymus chinensis hay TMR). Miyaji et al. [39] reported a starch loss by $22.8 \%$ (on average) in TMR silages containing steam-flaked corn or brown rice and stored for $210 \mathrm{~d}$. Nevertheless, in TMR silage, the starch concentration tends to be similar to the fresh TMR due to the consumption of other nutrients during fermentation.

In addition to starch loss, ensiling often increases starch digestibility, especially in cereals with a greater content of prolamins in their endosperm (e.g., flint corn and sorghum) [14,40]. Prolamins are hydrophobic proteins that surround the starch granules, impairing starch digestion. Protease activity during ensiling reduces prolamin concentration and increases starch availability $[37,40,41]$. In a meta-analysis, Daniel et al. [42] (pp. 306-307) showed that the starch digestibility markedly increased with storage length in whole plant corn silage. The authors reported an increase in starch digestibility by $2.8 \mathrm{~g} \cdot \mathrm{kg}^{-1}$ per day until day 30 of storage and after this phase, it continued to increase linearly up to $570 \mathrm{~d}$, but at a lower rate $\left(0.3 \mathrm{~g} \cdot \mathrm{kg}^{-1}\right.$ per day). For high moisture corn silages, improvements in starch digestibility also occur with extended storage time. Da Silva et al. [43] modeled the ruminal in situ DM degradability of high moisture corn silage and reported an increase of $3 \mathrm{~g} . \mathrm{kg}^{-1}$ per day until $71 \mathrm{~d}$ of storage. After $71 \mathrm{~d}$ of storage, the DM degradability proceeds to increase linearly but at a rate ten-fold lower ( $0.3 \mathrm{~g} . \mathrm{kg}^{-1}$ per day). Hence, an increase of starch digestibility is likely to occur in TMR silages.

Miyaji et al. [39] reported an increase in ruminal starch degradation with a greater benefit in a TMR silage containing steam-flaked corn (by 6.83\%) than brown rice (by $1.57 \%$ ). A pronounced enhancement in starch digestibility is expected for dry ground or dry rolled corn (or sorghum) when ensiled as part of a TMR if stored for at least two months (based on data of high moisture corn silage). Such an increase in starch digestibility has been associated with higher feed efficiency in animals fed TMR silages $[44,45]$.

\subsubsection{Cell Wall Polysaccharides}

The plant cell wall is a complex matrix of polysaccharides, mainly consisting of cellulose, hemicellulose, and pectin. Although soluble carbohydrates from the cell content are the main fuel for microbes during ensiling, in a minor proportion, the constituents of the cell wall may also be cleaved and used as a substrate for silage fermentation [18] (pp. 95-139). Such partial breakage of cell wall polymers is likely favored in silages with higher moisture content. For instance, in alfalfa silage, Jones et al. [46] reported a decrease in constituents of cell wall carbohydrates (e.g., uronics, rhamnose, 
arabinose, and galactose) in low DM silage (290 g. $\mathrm{kg}^{-1}$ as fed), whereas in high DM silage (400 g. $\mathrm{kg}^{-1}$ as fed), no changes were observed.

Weinberg et al. [6] reported NDF loss (recovery of $880 \mathrm{~g} \cdot \mathrm{kg}^{-1}$ ) and a lower content of NDF (340 vs. 380 g.kg ${ }^{-1} \mathrm{DM}$ ) in a TMR ensiled for $140 \mathrm{~d}$ compared with the fresh TMR (both with DM of $500 \mathrm{~g} \cdot \mathrm{kg}^{-1}$ as fed). The same authors did not find a loss of NDF or alterations in NDF concentration (NDF of 380 g.kg ${ }^{-1}$ DM on average) in a similar TMR ensiled with higher DM content (DM of $648 \mathrm{~g}^{\mathrm{kg}} \mathrm{kg}^{-1}$ as fed).

Ning et al. [19] examined the occurrence of carbohydrate losses and hemicellulase activity in TMR silages. They did not observe hemicellulase activity after $14 \mathrm{~d}$ of storage, but hemicellulose loss continuously increased in both silages up to $56 \mathrm{~d}$ of storage, probably due to acid hydrolysis (by $19.9 \%$ in alfalfa hay TMR and by $23.5 \%$ in Leymus chinensis hay TMR). Compared to fresh TMR, Wang et al. [13] observed a reduction in NDF content in an ensiled TMR formulated with whole crop corn during $56 \mathrm{~d}$ of storage (NDF of 460 vs. $430 \mathrm{~g} \cdot \mathrm{kg}^{-1} \mathrm{DM}$ ), whereas the acid detergent fiber (ADF) concentration did not change during storage ( $270 \mathrm{~g} . \mathrm{kg}^{-1}$ on average), suggesting the occurrence of hemicellulose hydrolysis. Kondo et al. [20], on the other hand, did not observe changes in NDF concentration after ensiling a TMR, regardless of the length $(30 \mathrm{~d}$ or $90 \mathrm{~d})$ and temperature ( 15 or $30^{\circ} \mathrm{C}$ ) of storage. Xu et al. [7] partially replaced timothy and alfalfa hay by wet coffee grounds in a TMR silage $\left(0,100\right.$, or 200 g. $\left.\mathrm{kg}^{-1} \mathrm{DM}\right)$ and reported a linear increase in the NDF and ADF content and a linear decrease in apparent digestibility of NDF and ADF with the inclusion of coffee grounds. Hence, cell wall hydrolysis and changes in fiber content and digestibility during ensiling are mainly dependent on the ingredients included in the TMR.

In alfalfa and orchardgrass silages, Yahaya et al. [47] observed that ensiling slightly reduced the concentrations of hemicellulose and pectin, whereas changes in cellulose concentrations were inconsistent. Compared to fresh forage, hemicellulose and pectin decreased by $2.9 \%$ and $1.5 \%$ in alfalfa silage and by $4.1 \%$ and $1.2 \%$ in orchardgrass silage, respectively. In Napier grass silage, Desta et al. [48] reported a slight decrease of fiber entities during $90 \mathrm{~d}$ of storage (NDF by $2.2 \%$, ADF by $1.2 \%$, hemicellulose by $3 \%$ and cellulose by $1.9 \%$ ).

Although lignin is not a carbohydrate, it is closely related to polysaccharides in the cell wall. Classically, lignin has been assumed to be undegradable under anaerobic conditions. In fact, most silages have higher lignin concentrations than their fresh crops due to the disappearance of soluble nutrients. However, lignin is not completely recovered after ensiling. Recently, Machado et al. [49] examined the effects of an enzymatic complex on the recovery of nutrients in whole-plant corn and sugarcane silages. For lignin assayed as acetyl bromide lignin, these researchers reported recoveries of 840 and $810 \mathrm{~g} \mathrm{~kg}^{-1}$ for untreated corn and sugarcane silages, respectively. In both silages, lignin recovery linearly decreased with enzyme dose (from 840 to 540 and from 810 to $690 \mathrm{~g} \mathrm{~kg}^{-1}$, respectively), while the contents of flavonoids and polyphenols steeply increased, resulting in silages with greater antioxidant capacity.

\subsection{Proteins}

During silage fermentation, $\mathrm{N}$ loss may occur; however, they are normally less expressive than other soluble fractions with minor effects on the total content of crude protein (CP) [18] (pp. 95-139). Silages with slightly higher $\mathrm{CP}$ contents than their crops are not rare due to the consumption of other nutrients, primarily soluble carbohydrates. On the other hand, protein breakdown undergoes extensively during fermentation. The partial transformation of true protein into nonprotein compounds due to ensiling is an inevitable process performed by plant and microbial enzymes [50].

The occurrence of proteolysis in high-CP forages (e.g., legumes, temperate grasses) is undesirable and leads to poorer N use efficiency (NUE) [51,52]. However, in corn and sorghum silages (whole plant or grain silages), proteolysis has been positively associated with starch digestibility due to the degradation of hydrophobic proteins (prolamins) that surround the starch granules [40]. Such an increase in starch digestibility often results in the greater synthesis of ruminal microbial protein and, in turn, higher NUE [53-55]. Nevertheless, in conventional (non-ensiled) TMR, protein sources 
(e.g., heat-treated soybean meal) are incorporated into the ration to balance any loss of true protein during the storage of ensiled ingredients and, in turn, meet the requirements of metabolizable protein. In TMR silages, however, all ingredients are ensiled. Therefore, all protein sources are exposed to proteolysis.

During ensiling, protein degradation occurs in two phases. Primarily, protein hydrolysis occurs due to plant and microbial proteases, resulting in peptides and free amino acids (AA) $[18,50,56,57]$. Afterwards, the decarboxylation of AA leads to the formation of biogenic amines and carbon dioxide, whereas the deamination of $\mathrm{AA}$ results in $\mathrm{NH}_{3}$ and organic acids $[58,59]$.

Heron et al. [57] and Kemble [56] observed that ryegrass and timothy silages sterilized before ensiling still present high amounts of free AA, indicating a large contribution of plant enzymes to proteolysis. In wilted alfalfa silage, Ding et al. [60] reported that ensiling increased the proportion of nonprotein $\mathrm{N}\left(\mathrm{NPN}\right.$ ) from 260 to $730 \mathrm{~g} \mathrm{~kg}^{-1}$ of total $\mathrm{N}$ and that plant enzymes contributed approximately $2 / 3$ of the proteolysis, whereas microorganisms contributed $1 / 3$. Interestingly, most NPN remained as peptides ( $700 \mathrm{~g} \mathrm{~kg}^{-1}$ of NPN), which is more efficiently used by both ruminal microorganisms and animal than $\mathrm{NH}_{3}-\mathrm{N}$ [61] (pp. 219-240). In rehydrated corn grain silage, however, Junges et al. [41] reported that bacterial enzymes were the major responsible for proteolysis $(60 \%)$ followed by plant proteases $(30 \%)$. Fungi enzymes and fermentation products contributed approximately $5 \%$ of the proteolysis during fermentation. In TMR silages, which are mixtures of ingredients, we did not find any report that accounted for the contribution of microorganisms and plant proteases to proteolysis. Meanwhile, enterobacteria, clostridia, and bacilli are the main candidates involved in protein breakdown during silage storage [12,50].

The extent of protein transformation during ensiling is determined by factors capable of altering enzyme and microbial activities, such as $\mathrm{pH}$, moisture, temperature, and storage length. In general, a rapid $\mathrm{pH}$ decrease below 4 notably reduces protein breakdown [57,62-64]. However, protein degradation may continue during extended storage [40]. In TMR silages, ingredient sources may also affect proteolysis.

Hao et al. [17] evaluated the effects of moisture content (400, 450, and $500 \mathrm{~g} \mathrm{~kg}^{-1}$ of moisture) and storage length (from 0 to $56 \mathrm{~d}$ ) and reported no differences in total $\mathrm{N}$ content in TMR silages. Nevertheless, higher moisture content increased the concentrations of NPN, free AA, and $\mathrm{NH}_{3}-\mathrm{N}$ during fermentation. No effect was observed on the content of peptides. Although proteolysis continuously increased during storage, major transformations in $\mathrm{N}$ fractions were observed within the first week of storage. According to the authors, on d 56 of storage, $430 \mathrm{~g} \mathrm{~kg}^{-1}$ of N was NPN. Kondo et al. [20] observed that storage length and temperature influenced the concentrations of soluble protein (SP) and $\mathrm{NH}_{3}-\mathrm{N}$ in TMR silage. The authors reported no differences of SP in ensiled TMR stored for $30 \mathrm{~d}$ compared with fresh TMR, whereas extended storage ( $90 \mathrm{~d})$ increased SP concentration. In addition, silage stored at $30{ }^{\circ} \mathrm{C}$ had a higher content of SP than silage stored at $15^{\circ} \mathrm{C}$. The $\mathrm{NH}_{3}-\mathrm{N}$ increased with temperature and length of storage.

Nishino et al. [65] reported a lower synthesis of biogenic amines (histamine, cadaverine, tyramine, and putrescine) in TMR silage compared with whole-plant corn and wilted festulolium silages, possibly because of the ingredients used to formulate TMR (dry grains and heat-treated byproducts) were less susceptible to proteolysis, reducing substrates (free AA) for biogenic amine synthesis.

Recently, we compared the N fractionation in TMR silages (untreated with silage additives) containing different sources of $\mathrm{CP}$ (urea, soybean grain, and soybean meal) for finishing beef cattle [45]. As expected, ensiled TMR had higher proportions of $\mathrm{NH}_{3}-\mathrm{N}$ (A1 fraction) than fresh TMR, but the values remained within acceptable levels $\left(<100 \mathrm{~g} \mathrm{~kg}^{-1}\right.$ of $\left.\mathrm{N}\right)$, except for the TMR silage formulated with urea. The proportion of the A2 fraction (non-ammonia SP, including soluble true protein) also increased in ensiled TMR due to the proteolytic process. On the other hand, the insoluble $\mathrm{N}$ fractions (insoluble true protein (B1), fiber-bound protein (B2), and indigestible protein (C)) decreased during ensiling. Combining $\mathrm{N}$ fractionation outcomes enabled the content of rumen-degraded protein (RDP) of each ration to be estimated. Except for the TMR silage containing urea, all ensiled rations contained 
similar concentrations of RDP, including the ensiled ration supplemented with soybean meal before each feeding. Supplying nonfermented soybean meal at feeding or ensiling it with other ingredients altered the content of RDP or RUP only $2 \mathrm{~g} \mathrm{~kg}^{-1} \mathrm{DM}$.

In brief, proteolysis extension seems to be lower in TMR silages (except for urea-containing TMR) than we usually see in high-CP forages (e.g., alfalfa and temperate grasses), mainly due to the higher DM content. Additionally, the use of byproducts that have undergone washing and/or heating during food processing (at agroindustry) might also decrease protein fractions that are susceptible to proteolysis, both during ensiling and rumen fermentation. Of course, the content of RUP in TMR silage is lower than in fresh TMR, but it does not mean that RDP/RUP cannot be balanced in the diet. From our perspective, more research is merited to define and predict patterns of proteolysis for a given ingredient or a combination of ingredients and, ultimately, allow the supply of adequate amounts of metabolizable protein to meet animal requirements.

\subsection{Lipids}

In complete rations, grains, oilseeds, and byproducts contribute most to lipid content. Overall, linolenic acid (C18:3 n-3) is the main fatty acid (FA) in forages, whereas cereals and oilseeds are rich in linoleic acid (C18:2n-6). Palmitic acid (C16:0), stearic (C18:0), and oleic (C18:1) acids are also representative FA in forages and concentrates [66-68].

In well-sealed silos, the lack of oxygen generates an excess of reducing equivalents (e.g., nicotinamide adenine dinucleotide in reduced form), which constrains the use of reduced molecules to produce energy, such as FA [69]. Hence, FA are not usual fuels for fermentation [70]. In this way, well-conserved silages will present similar content of total fat as in fresh material $[66,68]$. However, changes in proportions of individual FA may occur in silages $[67,68]$.

A higher proportion of free (non-esterified) FA has been reported for silages in comparison with the corresponding fresh crop. Elgersma et al. [71] reported that only $20 \mathrm{~g} \mathrm{~kg}^{-1}$ of FA were in their free form in fresh ryegrass, whereas after ensiling, this level increased to $500 \mathrm{~g} \mathrm{~kg}^{-1}$ of FA in ryegrass silage. Lipases and lipoxygenases are associated with lipolytic activity during ensiling. Lipases (carboxylic ester hydrolase) are present in fresh forages and grains [67,68,72], and they can cleave ester bonds of triglycerides, thereby releasing glycerol and free FA [73]. Under certain conditions, the free FA may undergo lipoxygenase action. Lipoxygenases can oxidize free FA, mainly linoleic and linolenic acids, initially producing hydroperoxides that are later cleaved in aldehydes and ketones [74,75]. Lipase and lipoxygenase activities are elevated soon after harvesting or in poorly preserved silages. However, lipase and lipoxygenase activities are altered by $\mathrm{pH}$ or temperature variation. Optimum conditions for lipase activity are near $24^{\circ} \mathrm{C}$ and $\mathrm{pH} 8$ [73]. For lipoxygenase, optimal activity occurs in neutral to basic $\mathrm{pH}$ conditions (6.5 to 8.0) [76]. This finding means that rapid acidification might preclude the cleavage of FA and the formation of some aldehydes in silages.

Although plant enzymes seem to be primarily responsible for lipolysis, some bacteria found in silage possess biohydrogenation activity and may reduce the content of unsaturated FA [68]. Ding et al. [60] observed a decrease in unsaturated FA (C18:2n-6 and C18:3n-6) in control (by 43\%) or sterile silages (by $28 \%$ ), whereas autoclave-treated silages (to inhibit plant enzymes and microbial activity) had a similar profile of FA compared to fresh forage; however, control silage presented a higher level of FA C16:0 compared to fresh forage (alfalfa). Liu et al. [68] also reported more FA C16:0 in oat silage compared to fresh crop. Han and Zhou [77] observed alterations in the main FA present in corn silage (C16:0, C18:0, C18:1, C18:2, and C18:3) during the first $2 \mathrm{~d}$ after ensiling. According to the authors, saturated FA increased in favor of a decrease of unsaturated FA. These results were attributed to lipoxygenase activity, which benefited from the high $\mathrm{pH}$ observed during the first hours after ensiling.

Liu et al. [67] evaluated changes in the FA composition of alfalfa silage in relation to temperature $\left(15,30\right.$, and $\left.45^{\circ} \mathrm{C}\right)$ and length of storage $(0$ to $65 \mathrm{~d})$. The decrease observed in the total FA content, as well as in C18:1 and C18:3n3, was greater on the first day of fermentation than on the remaining 65 
$\mathrm{d}$ of storage. In addition, losses of FA were higher at $45^{\circ} \mathrm{C}$ than at lower temperatures. The authors attributed those results to the thermolability of FA, as well as an increase in LAB development at higher temperatures. However, on d 65 of storage silages kept at $15^{\circ} \mathrm{C}$ had the lowest amount of total FA. The authors attributed this result to an enhanced activity of aerobic bacteria, yeasts, and plant lipoxygenase. Recently, Lazzari [45] observed no alteration in the FA profile of TMR silages, either supplement or not with rolled soybean grain.

In brief, in well-preserved silages, the content of total FA is not expected to change expressively, once FA are not usual fuels for fermentation. An increase in free FA and changes in the concentration of specific FA, such as a decrease in unsaturated FA, may occur, especially under suboptimal conditions of ensiling management.

\subsection{Minerals}

As a rule, well-preserved silages have slightly higher ash contents than their fresh crops [78,79], due to the disappearance of organic matter. However, the contents of specific minerals may change during ensiling. Schlegel et al. [80] observed higher concentrations of Mn (by 65\%), $\mathrm{Na}$ (by 33\%), Se (by $27 \%$ ), Zn (by 13\%) and $\mathrm{Mg}$ (by 12\%) in grass and legume silages compared with their respective herbages due to a loss of fermentable nutrients and possible soil contamination. No changes were observed in the $\mathrm{Ca}, \mathrm{P}, \mathrm{K}, \mathrm{Cl}, \mathrm{S}$, and $\mathrm{Cu}$ contents.

Microbial development and low $\mathrm{pH}$ conditions have been related to the higher availability of minerals in silage. Lee et al. [81] reported that some LAB strains possess the ability to increase the bioavailability of inorganic selenium during silage fermentation by converting sodium selenite into organic selenium. Hansen and Spears [82] observed that ensiling increased Fe availability in whole-plant corn silage, probably because of the acidic conditions in silage. Ibrahim et al. [83] evaluated the ruminal solubility of minerals in feedstuffs used in ruminant nutrition. They reported higher ruminal availability of minerals $(\mathrm{Ca}, \mathrm{Mg}, \mathrm{P}, \mathrm{Na}, \mathrm{K}, \mathrm{Cu}$, and $\mathrm{Zn}$ ) in corn silage, despite the lower content of ash in corn silage compared to other tested feeds. Overall, the ruminal availability of minerals in corn silage was above $800 \mathrm{~g} \mathrm{~kg}^{-1}$ (from 700 to $1000 \mathrm{~g} \mathrm{~kg}^{-1}$ ), which was also attributed to the effect of low silage $\mathrm{pH}$ (3.7 in the mentioned study). Rooke et al. [84] also reported high availability of minerals $(\mathrm{K}, \mathrm{Ca}, \mathrm{Na}, \mathrm{P}, \mathrm{Mg}$, and $\mathrm{Cu})$ in grass silage $\left(>930 \mathrm{~g} \mathrm{~kg}^{-1}\right.$ on average).

Beyond the acidity effect, phytate and oxalate interact with minerals (e.g., $\mathrm{Ca}, \mathrm{Mg}, \mathrm{Zn}, \mathrm{Fe}, \mathrm{Cr}$, and $\mathrm{Mn}$ ), reducing their bioavailability [85]. However, Hummer et al. [86] reported lower phytate in fermented corn grain (by 32\%) and Giang [87] found a lower concentration of oxalate (by 59\%) in Colocasia esculenta silage, suggesting that phytate and oxalate degradation during fermentation might also contribute to the higher availability of minerals in silages.

Although there is a lack of information on the fate of minerals in ensiled TMR, one would expect minor changes in their concentrations but an increase in their availability, as previously reported for other silages.

\subsection{Vitamins}

Vitamins are complex molecules essential for different metabolic pathways [88]. Vitamins are classified as fat-soluble (A, D, E, and K) and water-soluble (B and C) [89]. Adult ruminants are less dependent on exogenous sources of vitamins than nonruminants. Vitamins from $\mathrm{B}$ and $\mathrm{K}$ complexes are synthesized within the rumen by microorganisms; vitamin $\mathrm{D}$ is produced from steroids present in the skin after sunlight exposure; glucose and galactose are converted in vitamin $C$ when required [88]. In this way, fat-soluble vitamins, mainly $\mathrm{A}$ and $\mathrm{E}$, are more required from exogenous sources. The carotenes (provitamin A) and tocopherols (vitamin E) present in fresh forages are the main sources of those vitamins, although grains may also contribute [90-93].

Forage conservation (haying and ensiling) has been generically linked to losses of carotenoids and tocopherols, but losses related to ensiling are much smaller than for wilted forages and hay [94]. Carotenes and tocopherols are prone to oxidation after harvesting. Exposition to ultraviolet radiation 
(even in the dark), oxygen, high temperature, and lipoxygenase activity are the primary cause of carotene destruction $[90,91,95,96]$. Tocopherols are natural antioxidants protecting other molecules from oxidation; however, due to this protective activity, tocopherol may also be degraded [89].

Kalac and Kyzlink [97] reported that carotenoids are rapidly degraded when exposed to oxygen under low $\mathrm{pH}$ conditions ( $\mathrm{pH} 3.7$ to 4.2). In the same study, Kalac and Kyzlink [97] also informed that carotenoid degradation was greater within the temperature range of 30 to $40{ }^{\circ} \mathrm{C}$. On the other hand, a rapid lactic acid synthesis in the absence of oxygen had a positive correlation with $\beta$-carotene and $\alpha$-tocopherol concentration, which means that a rapid $\mathrm{pH}$ drop under anoxic conditions is beneficial to the conservation of (pro)vitamins as found in well-preserved silages [92,98]. Nozière et al. [91] and Liu et al. [68] reported losses of carotenes during ensiling by $20 \%$ (for silages in general) and $25.5 \%$ (for oat silage). Carotene loss during ensiling was attributed to lipoxygenase activity [68]. Tocopherol, on the other hand, was less degraded (11.6\%) than carotene [68]. This phenomenon has been attributed to a higher stability of tocopherol in anoxic conditions [68], as well as a possible activity of tocopherol-producing bacteria [99].

Silo structure, length of storage, additives, and temperature during storage are also important factors related to vitamin conservation. Nadeau et al. [100] (pp. 891-893) observed a reduction of vitamins in grass-legume silage stored in round bales. $\alpha$-Tocopherol and $\beta$-carotene decreased by $49 \%$ (from 35 to $18 \mathrm{mg} \mathrm{kg}^{-1} \mathrm{DM}$ ) and $37 \%$ (from 19 to $12 \mathrm{mg} \mathrm{kg}^{-1} \mathrm{DM}$ ), respectively, during three months of storage. However, vitamin contents in silages stored in bunker and tower silos were similar to vitamin contents in the fresh herbage. These results were attributed to a greater risk of oxygen infiltration and oxidation of vitamins in round-bale silos.

Jares [101] evaluated the concentrations of tocopherols $(\alpha, \gamma$, and $\delta)$ in rehydrated corn grain silages (320 g. $\mathrm{kg}^{-1}$ moisture) during storage $(0,21,38,63$ 100, and $185 \mathrm{~d}$ ) and observed a decrease along the storage time (tocopherols decreased from $57.7 \mu \mathrm{g} \mathrm{g}^{-1} \mathrm{DM}$ at ensiling to $44.4 \mu \mathrm{g} \mathrm{g}^{-1} \mathrm{DM}$ at $185 \mathrm{~d}$ of storage). Most of the reduction occurred during the first $21 \mathrm{~d}$ of fermentation. A reduction of tocopherols was also observed in dry grains, but ensiled grains had lower concentrations of tocopherols than dry grains.

Liu et al. [93] compared the effects of additives (fibrolytic enzymes, tert-butylhydroquinone, and tea polyphenols) and temperature $\left(15,30\right.$, and $\left.45^{\circ} \mathrm{C}\right)$ on vitamin concentrations in Napier grass silage. They found that the control silage stored at $30^{\circ} \mathrm{C}$ had more tocopherol than fresh forage or control silage kept at $15^{\circ} \mathrm{C}$. Ensiling reduced the content of carotenes independently of temperature, but carotene was higher in silage kept at $30^{\circ} \mathrm{C}$ than at 15 or $45^{\circ} \mathrm{C}$ According to the authors, silage stored at $30^{\circ} \mathrm{C}$ presented more tocopherol because of the probable activity of microorganisms capable of producing this molecule. Additives had no beneficial effect, except for tert-butylhydroquinone, which is an antioxidant. Lindqvist et al. [92] reported that bacterial inoculation (Lactobacillus plantarum and Pediococcus acidilactici) improved tocopherol concentration in red clover silage (50.1 vs. $34.2 \mathrm{mg} \mathrm{kg}^{-1}$ DM). In contrast, Liu et al. [68] observed a reduction in carotene due to Lactobacillus plantarum inoculation in oat silage. The use of propionic acid ( $4 \mathrm{~kg} \mathrm{t}^{-1}$ as fed), however, was effective in controlling carotene loss because carotene concentration in treated silage did not differ from fresh forage.

In brief, losses of carotene and tocopherols may occur during ensiling; however, tocopherol seems more stable than carotenes in silages. The TMR silages often contain exogenous sources of vitamins which, in terms of stability, may differ from natural sources of vitamins (or provitamins) present in feeds. To the best of our knowledge, the fate of natural and synthetic vitamins in TMR silage is unknown.

\subsection{Feed Additives}

Knowledge of the course of feed additives during ensiling is rare (e.g., ionophores, essential oils, tannins, probiotics, prebiotics, sodium bicarbonate, $\beta$-adrenergic agonists, etc.). Some studies have examined the effects of feed additives on silage conservation, but the fate of those additives is unknown. 
Hoon and Meeske [102] investigated the effect of lasalocid (an ionophore antibiotic) on the conservation of corn silage. It is worth noting that LAB are Gram-positive and ionophore-sensitive. Compared with untreated silage, lasalocid sodium $\left(0.15 \mathrm{~g} \mathrm{~kg}^{-1}\right.$ as fed) decreased lactic acid concentration and increased fermentative losses, resulting in silage with poorer organic matter digestibility in vitro. The treated silage also had a more intense aerobic deterioration, as indicated by the higher production of $\mathrm{CO}_{2}$ during air exposure. No information was provided on the concentration/activity of lasalocid at the silage feedout. Recently, Lazzari [45] reported that monensin concentration slightly decreased after ensiling TMR for beef cattle (33.8 to $31.6 \mathrm{mg} \mathrm{kg}^{-1} \mathrm{DM}$ ), suggesting partial degradation during fermentation. Nonetheless, all silages presented an adequate conservation ( $\mathrm{pH}$ below 4.8, lactic acid above $23 \mathrm{~g} \mathrm{~kg}^{-1} \mathrm{DM}$ and DM loss below $40 \mathrm{~g} \mathrm{~kg}^{-1} \mathrm{DM}$ ), as well as high aerobic stability (over $240 \mathrm{~h}$ ).

Kung Jr. et al. [103] examined the effect of a commercial blend of essential oils ( 40 or $80 \mathrm{mg} \cdot \mathrm{kg}^{-1}$ as fed) on the conservation of corn silage. The blend of essential oils did not affect the populations of yeasts, molds, lactic acid bacteria, or enterobacteria, the fermentation end-products, or the aerobic stability in corn silage. Foskolos et al. [104] investigated the effects of essential oils on protein degradation during ensiling. Five essential oil compounds (thymol, eugenol, cinnamaldehyde, capsaicin, and carvacrol) in four doses (from 0 to $2 \mathrm{~g} \mathrm{~kg}^{-1}$ as fed) were sprayed on ryegrass before ensiling. Thymol, eugenol, and cinnamaldehyde at $2 \mathrm{~g}$ and carvacrol at 0.5 and $2 \mathrm{~g} . \mathrm{kg}^{-1}$ inhibited deamination. Cinnamaldehyde at $2 \mathrm{~g} \mathrm{~kg}^{-1}$ resulted in silages with approximately $10 \%$ more true protein than other silages. However, the highest dose of the essential oils $\left(2 \mathrm{~g} \cdot \mathrm{kg}^{-1}\right)$ negatively affected the ensiling process by decreasing LAB counts and lactic acid concentration and increasing silage $\mathrm{pH}$. Recently, Pereira [105] studied the effects of essential oils (thymol and carvacrol) as additives in corn and sugarcane silages. In sugarcane silages, the addition of thymol, carvacrol, or a combination of thymol and carvacrol led to higher concentrations of soluble carbohydrates. The combination of thymol and carvacrol decreased lactic acid concentration. Carvacrol alone decreased the DM loss during fermentation, whereas thymol alone decreased the counts of $\mathrm{LAB}$ and ethanol concentration, whereas it increased the aerobic stability of sugarcane silage. In corn silage, LAB counts were reduced by thymol alone or combined with carvacrol. Carvacrol alone or in combination with thymol decreased the lactic acid concentration. All treated silages had less ethanol, lower DM loss during fermentation, and slightly higher aerobic stability upon air exposure. As in the aforementioned studies, no information was provided on the concentration of essential oils at silage feedout.

Even as discussed for nutrients in previous topics, feed additives may be altered during fermentation. In the meantime, the capacity of the additives to act in the rumen and host metabolism after undergoing fermentation warrants further investigation.

\section{Feeding Value of TMR Silages for Ruminants}

\subsection{Performance of Dairy Cows}

During the 1960s, TMR increased in dairy operations in the US, as milk production per cow increased, herds became larger, freestall and large-group handling of cows became more common, and milking parlors became more prevalent $[1,106]$. At nearly the same time, the first studies on TMR silages appeared in the literature.

Owen and Howard [2] evaluated the effects of ensiled TMR with different moisture levels $(680,530$, and $\left.470 \mathrm{~g} . \mathrm{kg}^{-1}\right)$, obtained by varying the period of alfalfa wilting, on the performance of dairy cows. The rations were composed of alfalfa (500 g.kg-1 DM) and cracked corn (500 g.kg $\left.{ }^{-1} \mathrm{DM}\right)$ and contained approximately $170 \mathrm{~g} . \mathrm{kg}^{-1}$ of CP (DM basis). Cows fed low- and medium-moisture rations (470 and 530 g.kg-1) had higher DM intake than cows fed high-moisture rations. However, milk fat content was higher for the high-moisture ration, which counterbalanced the differences in milk yield, resulting in a similar yield of fat-corrected milk (FCM) among treatments. The authors concluded that the use of TMR silage is a good alternative to simplify feeding management. 
Marshall and Voigt [107] compared the nutritive value of an ensiled TMR formulated with whole-plant corn treated with urea and a fresh TMR formulated with corn silage also treated with urea and moistened concentrate mix. The rations contained (DM basis) $610 \mathrm{~g} \cdot \mathrm{kg}^{-1}$ of corn silage and 390 g. $\mathrm{kg}^{-1}$ of concentrate mix (citrus pulp, cottonseed meal, urea, and minerals). The authors found no difference among treatments for cow performance $\left(20.2 \mathrm{~kg} . \mathrm{d}^{-1}\right.$ of FCM, DM intake of $32 \mathrm{~g} . \mathrm{kg}^{-1}$ of body weight (BW)).

Since the pioneering studies, ensiling TMR formulated with cereal grain was associated with higher feed efficiency. Hibbs and Conrad [44] compared fresh with ensiled TMR (without any silage additive) for dairy cows. In both diets, a rate of $0.45 \mathrm{~kg}$ of concentrate was mixed with $3.18 \mathrm{~kg}$ of corn silage (as-fed basis). The concentrate mix contained $291 \mathrm{~g} . \mathrm{kg}^{-1} \mathrm{DM}$ of CP and was composed of 573 g.kg-1 corn, 300 g. $\mathrm{kg}^{-1}$ soybean meal, 50 g.kg ${ }^{-1}$ dehydrated alfalfa meal, 35.2 g.kg-1 urea, 32 g. $\mathrm{kg}^{-1}$ bone meal, and 9.6 g. $\mathrm{kg}^{-1}$ salt. Both diets contained $140 \mathrm{~g} . \mathrm{kg}^{-1} \mathrm{DM}$ of CP. Total-tract DM digestibility increased (767 vs. 791 g.kg $\left.{ }^{-1} \mathrm{DM}\right)$ and DM intake decreased (18.1 vs. $16.3 \mathrm{~kg} . \mathrm{d}^{-1}$ ) for cows fed TMR silage, whereas there was no difference in milk yield (18.8 vs. $\left.19.0 \mathrm{~kg} . \mathrm{d}^{-1}\right)$. There was no difference in milk fat content and FCM among treatments (18.3 vs. $\left.18.7 \mathrm{~kg} . \mathrm{d}^{-1}\right)$. Therefore, feed efficiency (FCM/DM intake) was higher for cows fed TMR silage (1.01 vs. 1.15, for fresh and ensiled TMR, respectively).

In a second trial, Hibbs and Conrad [44] used the same proportion of corn silage and concentrate as in the previous trial to compare fresh and ensiled TMR (without any silage additive), but they altered the concentrate composition $\left(408 \mathrm{~g} \cdot \mathrm{kg}^{-1}\right.$ of corn, $500 \mathrm{~g} \cdot \mathrm{kg}^{-1}$ of soybean meal, $50 \mathrm{~g} . \mathrm{kg}^{-1}$ of dehydrated alfalfa, $32 \mathrm{~g} \cdot \mathrm{kg}^{-1}$ of bone meal, and $10 \mathrm{~g} \cdot \mathrm{kg}^{-1}$ of salt). Diet CP was similar to the first trial $\left(140\right.$ g.kg $\left.{ }^{-1} \mathrm{DM}\right)$. As in the first trial, DM intake was lower (17.1 vs. $\left.15.6 \mathrm{~kg} \cdot \mathrm{d}^{-1}\right)$, and feed efficiency (FCM/DM intake) was greater for cows fed ensiled TMR (1.17 vs. 1.32) without differences in FCM (19.9 vs. $20.4 \mathrm{~kg} . \mathrm{d}^{-1}$, for fresh and ensiled TMR, respectively).

Pardue et al. [108] evaluated the effect of ensiling on the nutritive value of a TMR for dairy cows. Two groups of ten Holstein cows (approximately $84 \mathrm{~d}$ postpartum) were assigned to a switch-back design with three 28-d periods to compare the ensiled TMR with the same fresh ingredients (silage and concentrate) but fed separately at each milking (Ctrl). Although the performance was similar, the ruminal concentration of volatile fatty acids was greater in cows fed the ensiled TMR (85.4 vs. $95.2 \mathrm{mM}$, for Ctrl and TMR silage, respectively), suggesting a higher ruminal degradability of the TMR silage.

After a temporal gap, the ruminant production industry has shown renewed interest in TMR silage, certainly due to the availability of moisture byproducts. In 2009, Wongnen et al. [109] evaluated the nutritive value of fresh or ensiled TMR (without any silage additive), containing whole or cracked cottonseed, for dairy cows. Four multiparous Holstein Friesian crossbred cows (48 \pm 12 days in milk and $450 \pm 13 \mathrm{~kg} \mathrm{BW}$ ) were assigned to a $4 \times 4$ Latin square design (21-d periods) with four dietary treatments in a $2 \times 2$ factorial arrangement (fresh or ensiled TMR $\times$ whole or cracked cottonseed). Rations contained (g.kg $\left.{ }^{-1} \mathrm{DM}\right)$ : chopped rice straw (200), cassava chip (400), soybean meal (70), cottonseed (100), dried brewers grain (50), tomato pomace (50), molasses (80), urea (15), salt (5), oyster shell (3), di-calcium phosphate (2), mineral-vitamin mix (3), sulfur (2), tallow (10), and sodium bicarbonate (10). Diets contained approximately (DM basis) $160 \mathrm{~g} \cdot \mathrm{kg}^{-1}$ of CP and $690 \mathrm{~g} \cdot \mathrm{kg}^{-1}$ of total digestible nutrients (TDN), with a DM content of $630 \mathrm{~g} \cdot \mathrm{kg}^{-1}$ as fed. Ruminal fermentation parameters $\left(\mathrm{pH}, \mathrm{NH}_{3}\right.$, and volatile fatty acids (VFA)) and performance were similar among diets (15.5 kg.d $\mathrm{d}^{-1}$ DM intake, $18.9 \mathrm{~kg} . \mathrm{d}^{-1} \mathrm{FCM}, 4.30 \%$ milk fat, and 3.34\% milk protein). However, TMR silage led to a lower proportion of oleic acid (C18:1) in milk fat (27.0 vs. $24.4 \%$ of total FA, for fresh vs. ensiled TMR). This response was likely due to the partial biohydrogenation of unsaturated FA during silage fermentation.

Recently, Miyaji and Nonaka [110] compared the performance of dairy cows fed fresh or ensiled TMR (without any silage additive). The TMR contained rye silage, beet pulp, soybean meal, mineral-vitamin mix, and dry-rolled or steam-flaked hulled rice. Ensiling improved starch (916 vs. 972 g. $\mathrm{kg}^{-1}$ of starch) and DM digestibility (723 vs. $776 \mathrm{~g} . \mathrm{kg}^{-1}$ of DM), tended to increase 
DM intake (22.4 vs. $\left.23.0 \mathrm{~kg} . \mathrm{d}^{-1}\right)$ and resulted in greater milk yield (36.4 vs. $37.6 \mathrm{~kg} . \mathrm{d}^{-1}$, for fresh and ensiled TMR, respectively). The ruminal concentration of VFA (97.1 vs. $101.8 \mathrm{mM}$ ) was slightly higher in cows fed ensiled TMR. Despite the higher ruminal fermentability, TMR silages led to slightly greater concentrations of ruminal $\mathrm{NH}_{3}\left(7.27 \mathrm{vs} .8 .81 \mathrm{mg} \mathrm{dL}^{-1}\right)$ and higher urinary $\mathrm{N}$ excretion (124 vs. $152 \mathrm{~g} \mathrm{~d}^{-1}$ ). In a companying paper, the authors reported higher ruminal degradability of $\mathrm{CP}$ for those TMR silages [39]. Meanwhile, compared with the fresh TMR, daily secretion of milk protein was higher in cows fed TMR silage (1.24 vs. $1.31 \mathrm{~kg} . \mathrm{d}^{-1}$, respectively) [110]. A potential of TMR silages for high-producing cows was demonstrated in this study.

\subsection{Performance of Growing Ruminants}

The TMR silages have also been used for feeding growing sheep and cattle. Cao et al. [111] reported the effects of ensiling a TMR (inoculated with Lactobacillus plantarum) on $\mathrm{N}$ balance, ruminal fermentation, and methane production in sheep. Compared with fresh TMR, ensiled TMR had higher

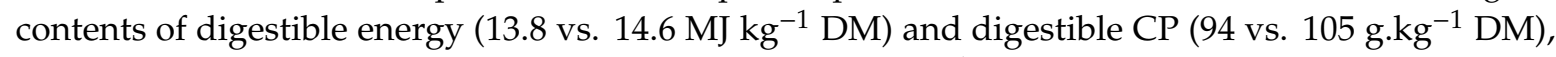
which contributed to lower fecal $\mathrm{N}$ excretion $\left(8.21 \mathrm{vs.} 7.08 \mathrm{~g} \mathrm{~d}^{-1}\right)$. On the other hand, ensiling the TMR increased the urinary $\mathrm{N}$ excretion $\left(9.76 \mathrm{vs} .11 .81 \mathrm{~g} \mathrm{~d}^{-1}\right)$. Meanwhile, $\mathrm{N}$ retention was similar between treatments $\left(5.2 \mathrm{~g} \mathrm{~d}^{-1}\right)$. The ruminal concentrations of total VFA ( 2 and $4 \mathrm{~h}$ after feeding) were higher in sheep fed TMR silage (88.4 and $87.4 \mathrm{mM}$ vs. 127 and $116 \mathrm{mM}$, for fresh and ensiled TMR, respectively). Compared to fresh TMR, the ensiled TMR reduced methane emissions by $10 \mathrm{~L} \mathrm{~d}^{-1}$, by $9.84 \mathrm{~L}$ per $\mathrm{kg}$ of DM intake, by $17.3 \mathrm{~L}$ per $\mathrm{kg}$ of digestible DM intake, by $0.54 \mathrm{~L}$ per $\mathrm{kg}$ of metabolic $\mathrm{BW}$, and by $20.9 \mathrm{~J}$ per $\mathrm{kJ}$ gross energy intake. The authors argued that lower methane production was due to the conversion of lactic acid (formed during silage fermentation) to propionic acid, an electron-consuming reaction in the rumen.

Meenongyai et al. [112] examined the effect of ensiling on the nutritive value of a grass-based TMR for beef cattle. Thirty crossbred Zebu-Holstein steers were blocked and received one of three experimental diets for $188 \mathrm{~d}$. The treatments were (1) fresh TMR with fresh Napier grass, (2) fresh TMR with Napier silage (untreated with silage additives), and (3) TMR silage (containing the Napier grass and untreated with silage additives). For treatments 1 and 2, forage and concentrate were mixed before feeding the animals. Experimental diets contained (g. $\left.\mathrm{kg}^{-1} \mathrm{DM}\right)$ : Napier grass (412), cassava pulp (60), cassava chip (50), corn (99.7), rice bran (140), palm kernel meal (69.1), soybean meal (50), sugar (91.6), salt (5), urea (20), and minerals (3). On average, diets had DM of $470 \mathrm{~g} . \mathrm{kg}^{-1}$ as fed and CP of 150 g. $\mathrm{kg}^{-1} \mathrm{DM}$. The $\mathrm{pH}$ values of rations 1,2 , and 3 were $4.7,4.0$, and 3.5, respectively. Total-tract DM digestibility was lower for the fresh TMR containing grass silage $\left(605 \mathrm{~g} . \mathrm{kg}^{-1} \mathrm{DM}\right)$ compared with fresh TMR containing fresh Napier grass $\left(711\right.$ g. $\left.\mathrm{kg}^{-1} \mathrm{DM}\right)$ or TMR silage $\left(655 \mathrm{~g} \cdot \mathrm{kg}^{-1} \mathrm{DM}\right)$. The DM intake, average daily gain (ADG), and feed efficiency were similar across treatments.

Recently, Lazzari [45] compared the nutritive value of TMR silages containing different protein sources for finishing beef cattle. Thirty-two Nellore heifers were blocked by initial BW and received one of four dietary treatments. The TMR silages contained (g. $\left.\mathrm{kg}^{-1} \mathrm{DM}\right)$ : sugarcane bagasse (130), rolled corn (594 to 684), corn gluten feed (150), limestone (6), mineral mix (20), and one of the following protein sources: urea (10), soybean meal (71), rolled soybean grain (100), or soybean meal (omitted at ensiling but supplied at TMR feeding = nonfermented) (71). All diets contained CP of $130 \mathrm{~g} \cdot \mathrm{kg}^{-1} \mathrm{DM}$ and roughage NDF of $105 \mathrm{~g} \cdot \mathrm{kg}^{-1} \mathrm{DM}$. The TMR silage formulated with soybean grain contained an ether extract (EE) content of 47 g. $\mathrm{kg}^{-1} \mathrm{DM}$, whereas the remaining diets contained approximately $30 \mathrm{~g} . \mathrm{kg}^{-1}$ $\mathrm{DM}$ of EE. There was no difference in animal performance (DM intake, ADG, carcass gain, dressing, and feed efficiency) among diets formulated with urea or soybean meal (ensiled or nonfermented). However, compared with other treatments, TMR silage containing soybean grain improved the ADG (1.22 vs. $\left.1.49 \mathrm{~kg} . \mathrm{d}^{-1}\right)$, mainly due to the higher DM intake (8.04 vs. $9.43 \mathrm{~kg} . \mathrm{d}^{-1}$ ) and, perhaps, lower ruminal methane emission due to the unsaturated FA from the soybean grain. Hence, balancing protein in TMR silage with urea or soybean meal (ensiled or not) does not affect the performance of finishing 
cattle. On the other hand, the inclusion of soybean grain (and perhaps other oilseeds) is a feasible strategy to improve the nutritive value of TMR silages for beef cattle.

\section{Final Remarks}

Marketing TMR silages represents a promising business opportunity for agroindustry, whereas feeding TMR silages is an alternative to simplify nutritional management. Among nutritional changes during TMR storage, a decrease in true-protein content and an increase in starch digestibility (which often leads to higher feed efficiency) have been consistently reported. Further research is warranted to fine-tune the supply of metabolizable protein, vitamins, and additives via TMR silages.

Author Contributions: J.L.P.D., conceived the review; J.L.P.D., A.V.I.B., and G.L. performed the literature research; J.L.P.D. and C.C.J. analyzed the scientific rigor; J.L.P.D. and C.C.J. coordinated the structure and scope of the topic; J.L.P.D., A.V.I.B., G.L., and C.C.J. wrote the paper. All authors have read and agreed to the published version of the manuscript.

Funding: This research received no external funding.

Conflicts of Interest: The authors declare no conflict of interest.

\section{References}

1. Schingoethe, D.J. A 100-Year Review: Total mixed ration feeding of dairy cows. J. Dairy Sci. 2017, 100, 10143-10150. [CrossRef] [PubMed]

2. Owen, F; Howard, W. Effect of ration moisture level on value of alfalfa plus cracked corn as a complete-feed silage for lactating cows. J. Dairy Sci. 1965, 48, 1310-1314. [CrossRef]

3. Schmidt, P.; Restelatto, R.; Zopollatto, M. Ensiling total mixed rations-An innovative procedure. In Proceedings of the V International Symposium on Forage Quality and Consservation, Piracicaba, Brazil, 16-17 July 2017; Nussio, L.G., Sousa, D.O., Gritti, V.C., Salvati, G.G.S., Santos, W.P., Salvo, P.A.R., Eds.; FEALQ: Piracicaba, Brazil, 2017; pp. 7-20.

4. Borreani, G.; Ferrero, F.; Tabacco, E. Baled silage management. In Proceedings of the 6th International Symposium on Forage Quality and Conservation, Piracicaba, Brazil, 7-8 November 2019; Nussio, L.G., Da Silva, E.B., Oliveira, K.S., Gritti, V.C., Salvo, P.A.R., Salvati, G.G.S., De Sousa, D.O., Eds.; ESALQ: Piracicaba, Brazil, 2019; pp. 219-246.

5. Nishino, N.; Harada, H.; Sakaguchi, E. Evaluation of fermentation and aerobic stability of wet brewers' grains ensiled alone or in combination with various feeds as a total mixed ration. J. Sci. Food Agric. 2003, 83, 557-563. [CrossRef]

6. Weinberg, Z.; Chen, Y.; Miron, D.; Raviv, Y.; Nahim, E.; Bloch, A.; Yosef, E.; Nikbahat, M.; Miron, J. Preservation of total mixed rations for dairy cows in bales wrapped with polyethylene stretch film-A commercial scale experiment. Anim. Feed. Sci. Technol. 2011, 164, 125-129. [CrossRef]

7. Xu, C.C.; Cai, Y.; Zhang, J.G.; Ogawa, M. Fermentation quality and nutritive value of a total mixed ration silage containing coffee grounds at ten or twenty percent of dry matter1. J. Anim. Sci. 2007, 85, 1024-1029. [CrossRef]

8. Restelatto, R.; Novinski, C.O.; A Silva, E.P.; Pereira, L.M.; Volpi, D.; Zopollatto, M.; Daniel, J.L.P.; Schmidt, P. Effects of holes in plastic film on the storage losses in total mixed ration silage in round bales. Transl. Anim. Sci. 2019, 3, 1543-1549. [CrossRef]

9. Gusmão, J.; Danes, M.; Casagrande, D.; Bernardes, T. Total mixed ration silage containing elephant grass for small-scale dairy farms. Grass Forage Sci. 2018, 73, 717-726. [CrossRef]

10. Weissbach, F.; Schmidt, L.; Hein, E. Method of anticipation of the run fermentation in silage making based on the chemical composition of the green fodder. In Proceedings of the 12th International Grassland Congress, Moscow, Russia, 11-20 June 1974; Iglovikov, V.G., Movsisyants, A.P., Eds.; Russian Academy of Agricultural Sciences: Lugovaya, Russia, 1974; pp. 663-673.

11. Kaiser, E.; Weiss, K.; Polip, I.V. A new concept for the estimation of the ensiling potential of forages. In Proceedings of the 13th International Silage Conference, Auchincruive, Scotland, 11-13 September 2002; Gechie, L.M., Thomas, C., Eds.; Scottish Agricultural College: Auchincruive, Scotland, 2002; pp. 344-358. 
12. Pahlow, G.; Muck, R.E.; Driehuis, F.; Elferink, S.J.W.H.O.; Spoelstra, S.F. Microbiology of Ensiling. In Silage Science and Technology; Buxton, D.R., Muck, R.E., Harrison, J.H., Eds.; American Society of Agronomy, Crop Science Society of America, and Soil Science Society of America: Madison, WI, USA, 2003; pp. 31-93.

13. Wang, H.; Ning, T.; Hao, W.; Zheng, M.; Xu, C. Dynamics associated with prolonged ensiling and aerobic deterioration of total mixed ration silage containing whole crop corn. Asian-Australas. J. Anim. Sci. 2015, 29, 62-72. [CrossRef]

14. Benton, J.R.; Klopfenstein, T.; Erickson, G.E. Effects of Corn Moisture and Length of Ensiling on Dry Matter Digestibility and Rumen Degradable Protein. In Nebraska Beef Cattle Reports; University of Nebraska-Lincoln: Lincoln, NE, USA, 2005; pp. 31-33.

15. Bueno, J.L.; Bolson, D.C.; Jacovaci, F.A.; Gomes, A.L.M.; Ribeiro, M.G.; Bueno, A.V.I.; Jobim, C.C.; Daniel, J.L.P. Storage length interacts with maturity to affect nutrient availability in unprocessed flint corn silage. Rev. Bras. Zootec. 2020, 49. [CrossRef]

16. Hao, W.; Wang, H.; Xu, C. Dynamic changes of proteolysis and microorganism composition of total mixed ration silages with different moisture levels. In Advances in Energy Science and Equipment Engineering, Proceedings of the International Conference on Energy Equipment Science and Engineering, Guangzhou, China, 30-31 May 2015; Zhou, S., Patty, A., Chen, S., Eds.; CRC Press: Balkema, Netherlands, 2015; pp. 269-273.

17. Hao, W.; Wang, H.L.; Ning, T.T.; Yang, F.Y.; Xu, C.C. Aerobic stability and effects of yeasts during deterioration of non-fermented and fermented total mixed ration with different moisture levels. Asian-Australas. J. Anim. Sci. 2015, 28, 816-826. [CrossRef]

18. Rooke, J.A.; Hatfield, R.D. Biochemistry of Ensiling. In Silage Science and Technology; Buxton, D.R., Muck, R.E., Harrison, J.H., Eds.; American Society of Agronomy, Crop Science Society of America, and Soil Science Society of America: Madison, WI, USA, 2003; pp. 95-139.

19. Ning, T.; Wang, H.; Zheng, M.; Niu, D.; Zuo, S.; Xu, C. Effects of microbial enzymes on starch and hemicellulose degradation in total mixed ration silages. Asian-Australas. J. Anim. Sci. 2016, 30, 171-180. [CrossRef] [PubMed]

20. Kondo, M.; Shimizu, K.; Jayanegara, A.; Mishima, T.; Matsui, H.; Karita, S.; Goto, M.; Fujihara, T. Changes in nutrient composition and in vitro ruminal fermentation of total mixed ration silage stored at different temperatures and periods. J. Sci. Food Agric. 2015, 96, 1175-1180. [CrossRef] [PubMed]

21. Daniel, J.L.P.; Nussio, L.G. Contribution of silage volatile compounds for the animal nutrition. In Proceedings of the II International Symposium on Forage Quality and Conservation, São Pedro, Brazil, 16-19 November 2011; Zopollatto, M., Daniel, J.L.P., Nussio, L.G., Sá Neto, A., Eds.; ESALQ: Piracicaba, Brazil, 2011; pp. 279-306.

22. Wang, C.; Nishino, N. Effects of storage temperature and ensiling period on fermentation products, aerobic stability and microbial communities of total mixed ration silage. J. Appl. Microbiol. 2013, 114, 1687-1695. [CrossRef] [PubMed]

23. Chen, L.; Guo, G.; Yuan, X.; Shimojo, M.; Yu, C.; Shao, T. Effect of Applying Molasses and Propionic Acid on Fermentation Quality and Aerobic Stability of Total Mixed Ration Silage Prepared with Whole-plant Corn in Tibet. Asian-Australas. J. Anim. Sci. 2014, 27, 349-356. [CrossRef] [PubMed]

24. Chen, L.; Yuan, X.-J.; Li, J.-F.; Wang, S.; Dong, Z.-H.; Shao, T. Effect of lactic acid bacteria and propionic acid on conservation characteristics, aerobic stability and in vitro gas production kinetics and digestibility of whole-crop corn based total mixed ration silage. J. Integr. Agric. 2017, 16, 1592-1600. [CrossRef]

25. Chen, L.; Yuan, X.J.; Li, J.F.; Dong, Z.H.; Wang, S.R.; Guo, G.; Shao, T. Effects of applying lactic acid bacteria and propionic acid on fermentation quality, aerobic stability and in vitro gas production of forage-based total mixed ration silage in Tibet. Anim. Prod. Sci. 2019, 59, 376. [CrossRef]

26. Klosterman, E.W.; Moxon, A.L.; Johnson, R.R.; Scott, H.W.; Van Stavern, J. Feeding value for fattening cattle of corn silages treated to increase their content of organic acids. J. Anim. Sci. 1961, 20, 493-496. [CrossRef]

27. Byers, J.; Davis, C.; Baylor, C. Feeding Value of limestone-treated corn silage for lactating dairy cows. J. Dairy Sci. 1964, 47, 1062-1064. [CrossRef]

28. Custódio, L.; Morais, G.; Daniel, J.L.P.; Pauly, T.; Nussio, C.M.B. Effects of chemical and microbial additives on clostridium development in sugarcane Saccharum officinarum L. ensiled with lime. Grassl. Sci. 2016, 62, 135-143. [CrossRef] 
29. Wagner, B.; Wenner, B.; Plank, J.; Poppy, G.; Firkins, J. Investigation of ammonium lactate supplementation on fermentation end products and bacterial assimilation of nitrogen in dual-flow continuous culture. J. Dairy Sci. 2018, 101, 8032-8045. [CrossRef]

30. Jaakkola, S.; Huhtanen, P. The Effect of lactic acid on the microbial protein synthesis in the rumen of cattle. Asian-Australas. J. Anim. Sci. 1989, 2, 398-399. [CrossRef]

31. Daniel, J.L.P.; Amaral, R.C.; Goulart, R.S.; Zopollatto, M.; Santos, V.P.; Filho, S.G.T.; Cabezas-Garcia, E.H.; Lima, J.R.; Nussio, C.M.B. Short-term effects of silage volatile compounds on feed intake and digestion in beef cattle1. J. Anim. Sci. 2013, 91, 2321-2331. [CrossRef] [PubMed]

32. Nkosi, B.; Meeske, R. Effects of ensiling totally mixed potato hash ration with or without a heterofermentative bacterial inoculant on silage fermentation, aerobic stability, growth performance and digestibility in lambs. Anim. Feed. Sci. Technol. 2010, 161, 38-48. [CrossRef]

33. Wang, F.; Nishino, N. Resistance to aerobic deterioration of total mixed ration silage: Effect of ration formulation, air infiltration and storage period on fermentation characteristics and aerobic stability. J. Sci. Food Agric. 2007, 88, 133-140. [CrossRef]

34. Nishino, N.; Hattori, H. Resistance to aerobic deterioration of total mixed ration silage inoculated with and without homofermentative or heterofermentative lactic acid bacteria. J. Sci. Food Agric. 2007, 87, 2420-2426. [CrossRef]

35. Chen, L.; Guo, G.; Yuan, X.; Zhang, J.; Li, J.; Shao, T. Effects of applying molasses, lactic acid bacteria and propionic acid on fermentation quality, aerobic stability and in vitro gas production of total mixed ration silage prepared with oat-common vetch intercrop on the Tibetan Plateau. J. Sci. Food Agric. 2015, 96, 1678-1685. [CrossRef]

36. Restelatto, R.; O Novinski, C.; Pereira, L.M.; A Silva, E.P.; Volpi, D.; Zopollatto, M.; Schmidt, P.; Faciola, A.P. Chemical composition, fermentative losses, and microbial counts of total mixed ration silages inoculated with different Lactobacillus species. J. Anim. Sci. 2019, 97, 1634-1644. [CrossRef]

37. Der Bedrosian, M.; Nestor, K.; Kung, L. The effects of hybrid, maturity, and length of storage on the composition and nutritive value of corn silage. J. Dairy Sci. 2012, 95, 5115-5126. [CrossRef]

38. Ferraretto, L.; Shaver, R.; Massie, S.; Singo, R.; Taysom, D.; Brouillette, J. Effect of ensiling time and hybrid type on fermentation profile, nitrogen fractions, and ruminal in vitro starch and neutral detergent fiber digestibility in whole-plant corn silage. Prof. Anim. Sci. 2015, 31, 146-152. [CrossRef]

39. Miyaji, M.; Matsuyama, H.; Nonaka, K. Effect of ensiling process of total mixed ration on fermentation profile, nutrient loss andin situruminal degradation characteristics of diet. Anim. Sci. J. 2016, 88, 134-139. [CrossRef]

40. Hoffman, P.; Esser, N.; Shaver, R.; Coblentz, W.; Scott, M.; Bodnar, A.; Schmidt, R.; Charley, R. Influence of ensiling time and inoculation on alteration of the starch-protein matrix in high-moisture corn. J. Dairy Sci. 2011, 94, 2465-2474. [CrossRef] [PubMed]

41. Junges, D.; Morais, G.; Spoto, M.H.F.; Santos, P.; Adesogan, A.; Nussio, C.M.B.; Daniel, J.L.P. Short communication: Influence of various proteolytic sources during fermentation of reconstituted corn grain silages. J. Dairy Sci. 2017, 100, 9048-9051. [CrossRef] [PubMed]

42. Daniel, J.L.P.; Junges, D.; Nussio, L.G. A meta-analysis of the effects of length of storage on starch digestibility and aerobic stability of corn silages. In Proceedings of the 17th International Silage Conference, Piracicaba, Brazil, 1-3 July 2015; Daniel, J.L.P., Morais, G., Junges, D., Nussio, L.G., Eds.; ESALQ: Piracicaba, Brazil, 2015; pp. 306-307.

43. Da Silva, N.C.; Nascimento, C.F.; Campos, V.M.; Alves, M.A.; Resende, F.D.; Daniel, J.L.P.; Siqueira, G.R. Influence of storage length and inoculation with Lactobacillus buchneri on the fermentation, aerobic stability, and ruminal degradability of high-moisture corn and rehydrated corn grain silage. Anim. Feed. Sci. Technol. 2019, 251, 124-133. [CrossRef]

44. Hibbs, J.W.; Conrad, H.R. Complete Ensiled Corn Rations for Lactating Dairy Cows; Ohio Agricultural Research and Development Center: Wooster, OH, USA, 1976; pp. 3-18.

45. Lazzari, G. Effects of Protein Source and Lipid Supplementation on the Performance of Finishing Beef Cattle Fed Total Mixed Ration Silages. Master's Thesis, State University of Maringá, Maringá, Brazil, 2020.

46. Jones, B.A.; Hatfield, R.D.; Muck, R.E. Effect of fermentation and bacterial inoculation on lucerne cell walls. J. Sci. Food Agric. 1992, 60, 147-153. [CrossRef] 
47. Yahaya, M.S.; Kimura, A.; Harai, J.; Nguyen, H.V.; Kawai, M.; Takahashi, J.; Matsuoka, S. Evaluation of structural carbohydrates losses and digestibility in alfalfa and orchardgrass during ensiling. Asian-Australas. J. Anim. Sci. 2001, 14, 1701-1704. [CrossRef]

48. Desta, S.T.; Yuan, X.; Li, J.; Shao, T. Ensiling characteristics, structural and nonstructural carbohydrate composition and enzymatic digestibility of Napier grass ensiled with additives. Bioresour. Technol. 2016, 221, 447-454. [CrossRef]

49. Machado, E. Use of Exogenous Lignocellulolytic Enzymes in Ruminant Nutrition. Ph.D. Dissertation, State University of Maringá, Maringá, Brazil, 2017.

50. McDonald, P.; Henderson, N.; Heron, S. The Biochemistry of Silage, 2nd ed.; Chalcombe Publicaitions: Marlow, UK, 1991; pp. 1-340.

51. Huhtanen, P.; Rinne, M.; Nousiainen, J. Effects of silage soluble nitrogen components on metabolizable protein concentration: A meta-analysis of dairy cow production experiments. J. Dairy Sci. 2008, 91, 1150-1158. [CrossRef]

52. Hymes-Fecht, U.; Broderick, G.; Muck, R.; Grabber, J. Replacing alfalfa or red clover silage with birdsfoot trefoil silage in total mixed rations increases production of lactating dairy cows. J. Dairy Sci. 2013, 96, 460-469. [CrossRef]

53. Wilkerson, V.; Glenn, B.; McLeod, K. Energy and nitrogen balance in lactating cows fed diets containing dry or high moisture corn in either rolled or ground form. J. Dairy Sci. 1997, 80, 2487-2496. [CrossRef]

54. Valadares, R.; Broderick, G.; Filho, S.D.C.V.; Clayton, M. Effect of replacing alfalfa silage with high moisture corn on ruminal protein synthesis estimated from excretion of total purine derivatives. J. Dairy Sci. 1999, 82, 2686-2696. [CrossRef]

55. Emeterio, F.S.; Reis, R.; Campos, W.; Satter, L.D. Effect of coarse or fine grinding on utilization of dry or ensiled corn by lactating dairy cows. J. Dairy Sci. 2000, 83, 2839-2848. [CrossRef]

56. Kemble, A.R. Studies on the nitrogen metabolism of the ensilage process. J. Sci. Food Agric. 1956, 7, $125-130$. [CrossRef]

57. Heron, S.J.E.; Edwards, R.A.; McDonald, P. Changes in the nitrogenous components of gamma-irradiated and inoculated ensiled ryegrass. J. Sci. Food Agric. 1986, 37, 979-985. [CrossRef]

58. Ohshima, M.; McDonald, P. A review of the changes in nitrogenous compounds of herbage during ensilage. J. Sci. Food Agric. 1978, 29, 497-505. [CrossRef]

59. Scherer, R.; Gerlach, K.; Südekum, K.-H. Biogenic amines and gamma-amino butyric acid in silages: Formation, occurrence and influence on dry matter intake and ruminant production. Anim. Feed. Sci. Technol. 2015, 210, 1-16. [CrossRef]

60. Ding, W.; Long, R.; Guo, X. Effects of plant enzyme inactivation or sterilization on lipolysis and proteolysis in alfalfa silage. J. Dairy Sci. 2013, 96, 2536-2543. [CrossRef]

61. Broderick, G.A.; Muck, R.E.; Pauly, T. Relationship between proteolysis in the silo and efficiency of utilization of dietary protein by lactating dairy cows. In Proceedings of the 3rd International Symposium on Forage Quality and Consservation, Campinas, Brazil, 22-23 July 2013; Daniel, J.L.P., Santos, M.C., Nussio, L.G., Eds.; FEALQ: Piracicaba, Brazil, 2013; pp. 219-240.

62. Virtanen, A.I. The AIV method of preserving fresh fodder. Emp. J. Exp. Agric. 1933, 1, 143-155.

63. McKersie, B.D. Effect of $\mathrm{pH}$ on proteolysis in ensiled legume Forage. Agron. J. 1907, 77, 81-86. [CrossRef]

64. E Heron, S.J.; Edwards, R.A.; Phillips, P. Effect of $\mathrm{pH}$ on the activity of ryegrass Lolium multiflorum proteases. J. Sci. Food Agric. 1989, 46, 267-277. [CrossRef]

65. Nishino, N.; Hattori, H.; Wada, H.; Touno, E. Biogenic amine production in grass, maize and total mixed ration silages inoculated with Lactobacillus casei or Lactobacillus buchneri. J. Appl. Microbiol. 2007, 103, 325-332. [CrossRef]

66. Alves, S.P.; Cabrita, A.R.J.; Jerónimo, E.; Bessa, R.J.; Fonseca, A.J.M. Effect of ensiling and silage additives on fatty acid composition of ryegrass and corn experimental silages. J. Anim. Sci. 2011, 89, 2537-2545. [CrossRef]

67. Liu, Q.; Dong, Z.; Shao, T. Dynamics of change in fermentation and fatty acid profiles in high moisture alfalfa silage during ensiling at different temperatures. Ciênc. Rural 2018, 48,1-11. [CrossRef]

68. Liu, Q.; Wu, J.; Shao, T. Roles of microbes and lipolytic enzymes in changing the fatty acid profile, $\alpha$-tocopherol and $\beta$-carotene of whole-crop oat silages during ensiling and after exposure to air. Anim. Feed. Sci. Technol. 2019, 253, 81-92. [CrossRef] 
69. Nelson, D.L.; Cox, M.M. Lehninger Principles of Biochemistry, 5th ed.; W. H. Freeman \& Co.: New York, NY, USA, 2008; pp. 485-901.

70. Mackie, R.I.; White, B.A.; Bryant, M.P. Lipid metabolism in anaerobic ecosystems. Crit. Rev. Microbiol. 1991, 17, 449-479. [CrossRef]

71. Elgersma, A.; Ellen, G.; Van Der Horst, H.; Muuse, B.; Boer, H.; Tamminga, S. Comparison of the fatty acid composition of fresh and ensiled perennial ryegrass (Lolium perenne L.), affected by cultivar and regrowth interval. Anim. Feed. Sci. Technol. 2003, 108, 191-205. [CrossRef]

72. De Barros, M.; Fleuri, L.F.; Macedo, G.A. Seed lipases: Sources, applications and properties-A review. Braz. J. Chem. Eng. 2010, 27, 15-29. [CrossRef]

73. Gadge, P.P.; Madhikar, S.D.; Yewle, J.N.; Jadhav, U.U.; Chougale, A.D.; Zambare, V.P.; Padul, M.V. Biochemical studies of lipase from germinating oil seeds (Glycine max). Am. J. Biochem. Biotechnol. 2011, 7, 141-145. [CrossRef]

74. Feussner, I.; Wasternack, C. The lipoxygenase pathway. Ann. Rev. Plant Boil. 2002, 53, 275-297. [CrossRef]

75. Senger, T.; Wichard, T.; Kunze, S.; Göbel, C.; Lerchl, J.; Pohnert, G.; Feussner, I. A Multifunctional lipoxygenase with fatty acid hydroperoxide cleaving activity from the moss Physcomitrella patens. J. Boil. Chem. 2004, 280, 7588-7596. [CrossRef]

76. Malekian, F.; Rao, R.M.; Prinyawiwatkul, W.; Marshall, W.E.; Windhauser, M.; Ahmedna, M. Lipase and Lipoxygenase Activity, Functionality, and Nutrient Losses in Rice Bran during Storage; LSU Agricultural Experiment Station Reports; Louisiana State University: Baton Rouge, LA, USA, 2000; pp. 3-56.

77. Han, L.; Zhou, H. Effects of ensiling processes and antioxidants on fatty acid concentrations and compositions in corn silages. J. Anim. Sci. Biotechnol. 2013, 4, 48. [CrossRef]

78. Meschy, F.; Baumont, R.; Dulphy, J.P.; Nozieres, M.O. Effet du mode de conservation sur la composition en éléments minéraux majeurs des fourrages (Effect of conservation on the major mineral concentration of forages). Rencontres Rech. Rumin. 2005, 12, 116.

79. Baumont, R.; Arrigo, Y.; Niderkorn, V. Transformation des plantes au cours de leur conservation et conséquences sur leur valeur pour les ruminants. Fourrages 2011, 205, 35-46.

80. Schlegel, P.; Wyss, U.; Arrigo, Y.; Hess, H.D. Changes in macro- and micromineral concentrations in herbage during the harvesting and conservation processes. Grass Forage Sci. 2018, 73, 918-925. [CrossRef]

81. Lee, M.R.F.; Fleming, H.R.; Cogan, T.; Hodgson, C.; Davies, D.R. Assessing the ability of silage lactic acid bacteria to incorporate and transform inorganic selenium within laboratory scale silos. Anim. Feed. Sci. Technol. 2019, 253, 125-134. [CrossRef]

82. Hansen, S.; Spears, J.W. Bioaccessibility of iron from soil is increased by silage fermentation. J. Dairy Sci. 2009, 92, 2896-2905. [CrossRef]

83. Ibrahim, M.N.M.; Van Der Kamp, A.; Zemmelink, G.; Tamminga, S. Solubility of mineral elements present in ruminant feeds. J. Agric. Sci. 1990, 114, 265-274. [CrossRef]

84. Rooke, J.A.; Akinsoyinu, A.O.; Armstrong, D.G. The release of mineral elements from grass silages incubated in sacco in the rumens of Jersey cattle. Grass Forage Sci. 1983, 38, 311-316. [CrossRef]

85. Fairweather-Tait, S.J. Bioavailability of dietary minerals. Biochem. Soc. Trans. 1996, 24, 775-780. [CrossRef]

86. Humer, E.; Wetscherek, W.; Schwarz, C.; Schedle, K. Effects of maize conservation techniques on the apparent total tract nutrient and mineral digestibility and microbial metabolites in the faeces of growing pigs. Anim. Feed. Sci. Technol. 2014, 197, 176-184. [CrossRef]

87. Giang, N.T. Effect of Taro (Colocasia esculenta) Foliage on the Performance of Growing Common Ducks. Master's Thesis, Swedish University of Agricultural Sciences, Sweden, 2010.

88. National Research Council. Nutrient Requirements of Dairy Cattle, 7th ed.; The National Academies Press: Washington, DC, USA, 2001; pp. 1-381.

89. McDowell, L.R. Vitamins in Animal and Human Nutrition, 2nd ed.; Iowa State University Press: Ames, IA, USA, 2000; pp. 1-793.

90. Kalač, P. Carotenoids, ergosterol and tocopherols in fresh and preserved herbage and their transfer to bovine milk fat and adipose tissues: A review. J. Agrobiol. 2012, 29, 1-13. [CrossRef]

91. Nozière, P.; Graulet, B.; Lucas, A.; Martin, B.; Grolier, P.; Doreau, M. Carotenoids for ruminants: From forages to dairy products. Anim. Feed. Sci. Technol. 2006, 131, 418-450. [CrossRef]

92. Lindqvist, H.; Nadeau, E.; Marker, S. Alpha-tocopherol and carotene in legume-grass mixtures as influenced by wilting, ensiling and type of silage additive. Grass Forage Sci. 2011, 67, 119-128. [CrossRef] 
93. Liu, Q.; Shao, T.; Bai, Y. The effect of fibrolytic enzyme, Lactobacillus plantarum and two food antioxidants on the fermentation quality, alpha-tocopherol and beta-carotene of high moisture napier grass silage ensiled at different temperatures. Anim. Feed. Sci. Technol. 2016, 221, 1-11. [CrossRef]

94. Carter, W.R.B. A review of nutrient losses and efficiency of conserving herbage as silage, barn-dried hay and field-cured hay. Grass Forage Sci. 1960, 15, 220-230. [CrossRef]

95. Kalač, P.; McDonald, P. A review of the changes in carotenes during ensiling of forages. J. Sci. Food Agric. 1981, 32, 767-772. [CrossRef]

96. Cardinault, N.; Doreau, M.; Nozière, P. Fate of carotenoids in the rumen. Rencontres Rech. Rumin. 2004, 11, 82.

97. Kalač, P.; Kyzlink, V. Losses of beta-carotene in red clover in an acid medium during ensiling. Anim. Feed. Sci. Technol. 1979, 4, 81-89. [CrossRef]

98. Müller, C.E.; Moller, J.; Jensen, S.K.; Udén, P. Tocopherol and carotenoid levels in baled silage and haylage in relation to horse requirements. Anim. Feed. Sci. Technol. 2007, 137, 182-197. [CrossRef]

99. Tani, Y.; Tsumura, H. Screening for tocopherol-producing microorganisms and alpha-tocopherol production by Euglena gracilis Z. Agric. Boil. Chem. 1989, 53, 305-312. [CrossRef]

100. Nadeau, E.; Johansson, B.; Jensen, S.K.; Olsson, G. Vitamin content of forages as influenced by harvest and ensiling techniques. In Proceedings of the 20th General Meeting of the European Grassland Federation, Luzern, Switzerland, 21-14 June 2004; Lüscher, A., Jeangros, B., Kessler, W., Huguenin, O., Lobsiger, M., Millar, N., Suter, D., Eds.; AGFF: Zurich, Switzerland, 2004; pp. 891-893.

101. Jareš, M. Changes in Content of Tocols during Storage of Ensiled Rehydrated Maize Grain. Master's Thesis, University of Zagreb, Faculty of Agriculture, Zagreb, Croatia, 2018.

102. Hoon, J.H.; Meeske, R. The effect of the inclusion of an ionophore as a silage additive on maize silage characteristics. Grootfontein Agric. 2011, 11, 75.

103. Kung, L.; Williams, P.; Schmidt, R.; Hu, W. A blend of essential plant oils used as an additive to alter silage fermentation or used as a feed additive for lactating dairy cows. J. Dairy Sci. 2008, 91, 4793-4800. [CrossRef] [PubMed]

104. Foskolos, A.; Cavini, S.; Ferret, A.; Calsamiglia, S. Effects of essential oil compounds addition on ryegrass silage protein degradation. Can. J. Anim. Sci. 2016, 96, 100-103. [CrossRef]

105. Pereira, L.M. Use of Essential Oils as Additives for Corn and Sugarcane Silages. Master's Thesis, Federal University of Paraná, Curitiba, Brazil, 2018.

106. McCoy, G.; Thurmon, H.; Olson, H.; Reed, A. Complete feed rations for lactating dairy cows. J. Dairy Sci. 1966, 49, 1058-1063. [CrossRef]

107. Marshall, S.; Voigt, A.R. Complete rations for dairy cattle. I. Methods of preparation and roughage-to-concentrate ratios of blended rations with corn silage. J. Dairy Sci. 1975, 58, 891-895. [CrossRef]

108. Pardue, F.; Fosgate, O.; O’Dell, G.; Brannon, C. Effects of complete ensiled ration on milk production, milk composition, and rumen environment of dairy cattle. J. Dairy Sci. 1975, 58, 901-906. [CrossRef]

109. Wongnen, C.; Wachirapakorn, C.; Patipan, C.; Panpong, D.; Kongweha, K.; Namsaen, N.; Gunun, P.; Yuangklang, C. Effects of fermented total mixed ration and cracked cottonseed on milk yield and milk composition in dairy cows. Asian-Australas. J. Anim. Sci. 2009, 22, 1625-1632. [CrossRef]

110. Miyaji, M.; Nonaka, K. Effects of altering total mixed ration conservation method when feeding dry-rolled versus steam-flaked hulled rice on lactation and digestion in dairy cows. J. Dairy Sci. 2018, 101, 5092-5101. [CrossRef]

111. Cao, Y.; Takahashi, T.; Horiguchi, K.-I.; Yoshida, N.; Cai, Y. Methane emissions from sheep fed fermented or non-fermented total mixed ration containing whole-crop rice and rice bran. Anim. Feed. Sci. Technol. 2010, 157, 72-78. [CrossRef]

112. Meenongyai, W.; Pattarajinda, V.; Stelzleni, A.M.; Sethakul, J.; Duangjinda, M. Effects of forage ensiling and ration fermentation on total mixed ration $\mathrm{pH}$, ruminal fermentation and performance of growing Holstein-Zebu cross steers. Anim. Sci. J. 2017, 88, 1372-1379. [CrossRef]

(C) 2020 by the authors. Licensee MDPI, Basel, Switzerland. This article is an open access article distributed under the terms and conditions of the Creative Commons Attribution (CC BY) license (http://creativecommons.org/licenses/by/4.0/). 